Prace Literackie LVII

Wrocław 2017

DOI: $10.19195 / 0079-4767.57 .9$

\title{
„Więc naprzód pies poczciwy kundel, który nas nigdy nie opuścił..." Wątki kynologiczne w wybranych wierszach polskich poetów XX w.
}

Obecność psa w literaturze europejskiej sięga czasów bardzo odległych, czego przykładem jest poemat Homera i zawarty w nim wzruszający obraz powitania wracającego z tułaczki Odyseusza przez wiernego Argosa. Homerowe wyobrażenie psiej wierności ukształtowało kolejne pokolenia pisarzy, co jednak w sposób szczególny uwidoczniło się dopiero w XIX i XX w. Spośród psów upamiętnionych w epickich utworach obcojęzycznych wymienić można krwiożerczego brytana (Pies Baskerville'ów Arthura Conan Doyle'a), spaniela (Flush: biografia Virginii Woolf), pudla (Podróże z Charleyem Johna Steinbecka), owczarka szkockiego (Lassie, wróć! Erica Knighta) i czworonożnych bohaterów książek Franza Kafki (Dociekania psa) i Gieorgija Władimowa (Wierny Rusłan). Mniej obfita jest bibliografia XIX- i XX-wiecznych utworów poetyckich, a wiersze Psu Kaczałowa Sergiusza Jesienina, Psia moc Rudyarda Kiplinga i Pies Jules'a Supervielle'a stanowią wyjątki na bez-kynologicznej mapie liryki.

W niniejszej pracy poddam analizie wiersze polskich poetów powstałe w XX w., nie uwzględniając przy tym utworów dedykowanych wyłącznie dzieciom, wskutek czego zabraknie kynologiczno-literaturoznawczych dywagacji na temat wierszy Ryszarda Marka Grońskiego (Po co właściwie trzymać psa), Ludwika Jerzego Kerna (Cztery łapy) i Jana Brzechwy (Jak rozmawiać trzeba z psem). Interpretacja poezji dla dzieci wymaga zastosowania odrębnych narzędzi metodologicznych, a w konsekwencji - mimo że stanowi zagadnienie bez wątpienia interesujące i godne uwagi - w tym przypadku nie znajduje kompozycyjnego uzasadnienia.

Celem artykułu jest analiza obecności psich motywów w twórczości poetyckiej Wisławy Szymborskiej (Monolog psa zaplatanego w dzieje), Konstantego Ildefonsa Gałczyńskiego (Sen psa), Krzysztofa Kamila Baczyńskiego (Psy), Zbi- 
gniewa Herberta (Naprzód pies) i Marii Pawlikowskiej-Jasnorzewskiej (Gtaszczac $p s a$ ). Artykuł ma charakter propedeutyczny i omawia najważniejsze zagadnienia, założenia i chwyty literackie służące zobrazowaniu motywu psa w wybranych wierszach.

Analizy utworów dokonać można z dwóch perspektyw:

— pies jako autor monologu lirycznego, postrzegający świat ze zwierzęcego punktu widzenia: Monolog psa zaplatanego w dzieje Szymborskiej i Sen psa Gałczyńskiego;

- pies jako przedmiot uwagi podmiotu lirycznego; obecność zwierzęcia stanowi pretekst do postawienia pytań o charakterze moralno-egzystencjalnym: Naprzód pies Herberta, Psy Baczyńskiego i Głaszczac psa Pawlikowskiej-Jasnorzewskiej.

Jak wspomniano, w wierszach Gałczyńskiego i Szymborskiej autorami monologu są psy. O ile jednak w Śnie psa podmiot liryczny jest postacią uniwersalną i niereprezentującą żadnego konkretnego zwierzęcia, o tyle w drugim przypadku mamy do czynienia z odniesieniem historycznym; autorką monologu jest bowiem Blondi, ulubiony pies Adolfa Hitlera. U Gałczyńskiego nie jest nawet znany wygląd, o rasie nie wspominając, tytułowego psa; natomiast analiza wiersza Monolog psa zaplatanego $w$ dzieje natychmiast wywołuje skojarzenia z krótkowłosą suką owczarka niemieckiego. Szymborska nie wspomina o imieniu Blondi i podobnie postępuje z Hitlerem; w przeciwieństwie do innego utworu poetki (Pierwsza fotografia Hitlera) dyktator ani razu nie zostaje wymieniony z imienia lub nazwiska. Warto zaznaczyć, że Blondi jest jednym z kilku zwierząt, którym Szymborska (traktując je również jako figury metaforyczne) poświęciła swe utwory. Są to na przykład: Małpa, Dwie matpy Bruegla, Kot w pustym mieszkaniu, Szkielet jaszczura. Dla psa natomiast (a raczej jego służącej do naukowych badań głowy) znalazło się miejsce w Eksperymencie.

Odwołania o charakterze historycznym znajdują odzwierciedlenie w nastroju wiersza. Opisane ze zwierzęcej perspektywy dzieje dyktatury Hitlera w nazistowskich Niemczech to dzieje psa, którego życie i sposób, w jaki go traktowano, obrazują początkowy triumf i stopniowy upadek Führera. Zespolenie Blondi i Hitlera pozwala wydobyć zazwyczaj niedostrzegany, schizofreniczny podział na relacje łączące zbrodniczego dyktatora z tymi, dzięki którym mógł sprawować władzę, oraz właściciela z wiernym psem. Blondi to faktycznie „pies zaplątany w dzieje", czego konsekwencją jest odczuwanie na własnej skórze zmian zachodzących w samym centrum obozu Hitlera. Makrokosmos wypadków wojennych przybiera formę mikrokosmosu, w środku którego nieżyjący już pies wspomina życie spędzone przy boku dyktatora. Zwraca uwagę dysproporcja między lękiem, fascynacją i czołobitnym stosunkiem, jaki żywili Niemcy w stosunku do Führera, i poufałością psa, łaszącego się do nóg i bezceremonialnie, aż żartobliwie ciągnącego go za ubranie. W monologu Blondi wyraźnie wybrzmiewa, że była ona jedyną istotą, którą Hitler naprawdę kochał. 
Podmiot liryczny utożsamiany z Blondi tak charakteryzuje relacje, jakie łączyły go z panem:

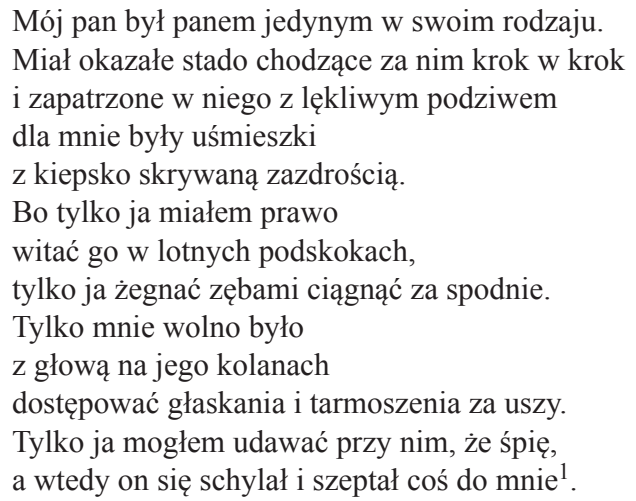

Dochodzi tutaj do zrównania ludzi i zwierząt, co służy semantycznemu zdegradowaniu służalczych i otumanionych obywateli do roli poddanych, bezwolnych istot. Mowa jest o „okazałym stadzie zapatrzonym z lękliwym podziwem”. Przeciwwagę dla bezwolnego thumu stanowi wielokrotne użycie zaimka osobowego „ja”, zestawionego ponadto z partykułą „tylko”. Również sposób zachowania krzyczącego na „poddanych” Hitlera zostaje określony jako „ujadanie” i „warczenie”. Irena Szczepankowska pisała:

Zaślepienie [...] to nazwa innego rodzaju aberracji poznawczej: metaforycznie ujmuje stan umysłu osoby zafiksowanej na określonej idei, fałszywym obrazie rzeczywistości, nieprzyjmującej do wiadomości niczego, co mogłoby zburzyć ten obraz. Modelem takiej konceptualizacji jest zapatrzenie się perceptora - sytuacja, w której określony obiekt pochłania całą uwagę patrzącego. Opisywane z psiej perspektywy „stado” podwładnych szefa było „zapatrzone w niego z lękliwym podziwem"2.

Sześć pierwszych zwrotek monologu Blondi stanowi autolaudację, skonfrontowaną następnie (strofy 7-11) ze smutnym opisem gwałtownego upadku z piedestału. Niepokój i dezorientację psa zwiększa nagła nieobecność pana, tak dotąd bliskiego towarzysza i opiekuna. Fakt zależności wysokiej pozycji Blondi w środowisku Hitlera od władzy, jaką on wówczas sprawował, najjaskrawiej ilustrują strofy dziewiąta i dziesiąta. Do głosu dochodzą najniższe ludzkie instynkty, nakazujące mścić się na zwierzęciu za porażkę właściciela. Nie mogąc (lub bojąc się) dokonać fizycznej zemsty na Führerze, niemieccy urzędnicy folgują emocjom, kopiąc miskę wygłodniałego psa, zrywając z karku kosztowną obrożę i dwukrotnie mierząc doń z pistoletu, pozostawiwszy postrzelone, krwawiące i wciąż żyjące zwierzę:

${ }^{1}$ Wszystkie cytaty z wiersza Szymborskiej pochodzą z książki: W. Szymborska, Dwukropek, Kraków 2005.

2 I. Szczepankowska, Człowiek, język, wizja świata w poezji Wisławy Szymborskiej. Studia semantyczne, Białystok 2013, s. 232. 


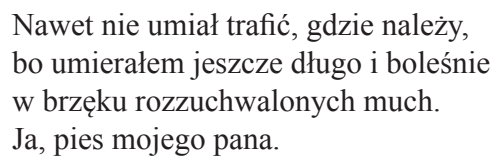

Wizja śmierci owczarka zaproponowana przez Szymborską kłóci się z najczęściej przywoływaną historyczną relacją, zgodnie z którą to sam Hitler, zdając sobie sprawę $\mathrm{z}$ tego, jakie są metody działania Rosjan, w obawie przed tym, co mogłoby spotkać psa, własnoręcznie go zastrzelił. Jednak, mimo świadomości kaprysów losu, Blondi, początkowo zdumiona zmianą sytuacji, do końca ma poczucie własnej wartości. W przeciwnym razie w ostatnim wersie w sposób pośredni, a mimo to jednoznaczny, nie przypomniałaby, że była psem wyjątkowym. Patrząc z perspektywy historycznoliterackiej, o wyjątkowości Blondi stanowi jej status naocznego świadka totalitaryzmu. 30 lat wcześniej konsekwencji totalitarnego systemu doświadczył tytułowy Rusłan z powieści Władimowa ${ }^{3}$.

W twórczości Szymborskiej niejednokrotnie pojawia się motyw śmierci. Według Małgorzaty Burzki-Janik na temat przemijania i końca egzystencji poetka mówi charakterystycznym dla siebie językiem ironii i paradoksów, opowiada bez lamentu i patosu, co sprawia, iż mimo odczuwania egzystencjalnego bólu zachwycamy się istnieniem, nawet jeśli trwa ono zaledwie [jak napisała Szymborska w Wielkiej liczbie — JJ] ,kilka znaków pazurkiem na piasku"4.

Badaczka wspomniała m.in. o Urodzinach, Nic dwa razy i Chwili, w których faktycznie nie sposób nie dostrzec pochwały istnienia. W Monologu psa zaplatanego $w$ dzieje ironia jest także obecna, jednak bardziej niż płaszczyzna języka obnaża ją kontekst historyczny. Nagła zmiana szokuje, lecz nie jedyny to przypadek strącenia władcy (wraz z jego dworem) z tronu. Ironią jest także fakt, że najbliższym dworzaninem jest pies - $\mathrm{i}$ to on jako pierwszy podzieli los pana. Opowieść jest rzeczowa i konkretna, podmiot liryczny zdaje relację z całego życia, dlatego perspektywa czasowa, a przy tym znajomość historii nie pozwalają zachwycić się przemijającym istnieniem. Nawet zdecydowana cezura (między 6 i 7 strofą) nie łagodzi beznamiętnego tonu monologu. Niezrozumienie przyczyny nagłej zmiany, jak w przypadku zwierzęcego bohatera z wiersza Kot w pustym mieszkaniu, dezorientuje. Od tego nie ma ucieczki, gdyż utrata jedynego pana to najgorsze, co spotkać może domowe zwierzę. Jednak w Kocie w pustym mieszkaniu wybrzmiewa pretensja, Blondi zaś godzi się z losem. To w pewnym sensie paradoks, gdyż kot wie (już od pierwszego wersu), że właściciel umarł, co powinno złagodzić ton niezadowolenia, pies natomiast jedynie zauważa, że pana nie

3 Studium porównawcze między wierszem Szymborskiej a powieścią Władimowa przedstawił Michał Jamiołkowski, Wierność - wartość czy antywartość? Funkcja bohatera zwierzęcego $w$ wybranych utworach literatury polskiej i obcej, [w:] Pies w kulturach świata, red. E. Skorupska-Raczyńska, J. Rutkowska, J. Żurawska-Chaszczewska, Gorzów Wielkopolski 2012, s. 183-189.

4 M. Burzka-Janik, ,, Tyle naraz świata ...” Szkice o poezji Wisławy Szymborskiej, Opole 2012, s. 41 . 
ma, a mimo to nie rodzi się w nim choćby pierwiastek gniewu. A przecież: znikać — tego nie robi się psu.

Zgoła odmiennie potraktował psa Konstanty Ildefons Gałczyński. Wiersz Sen psa ma charakter żartobliwy i przedstawia poetycki obraz marzenia sennego, w którym każdy element rzeczywistości przybiera postać kawałka mięsa. Stół ma nogi wołowe, w lesie zamiast drzew rosną kiełbaski, a w kalafiorach kości. W czwartej zwrotce czytamy:

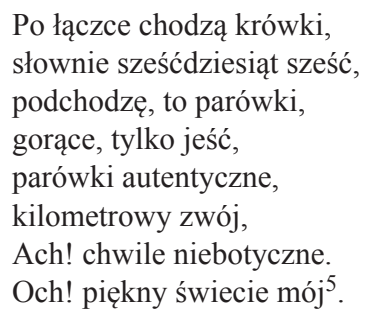

Po łączce chodzą krówki, słownie sześćdziesiąt sześć, podchodzę, to parówki, gorące, tylko jeść, parówki autentyczne, kilometrowy zwój, Ach! chwile niebotyczne.

Och! piękny świecie mój ${ }^{5}$.

W przeciwieństwie do Blondi, bezimienny pies u Gałczyńskiego nie próbuje analizować zawirowań historii, lecz trywializuje rzeczywistość, ograniczając ją ciasnymi ramami garmażeryjnych aromatów. Ostatni wers utworu: „zbaraniał cały świat" najlepiej ilustruje banalno-kulinarną wizję psiego raju. Jednak taka właśnie puenta pozwala dostrzec w podmiocie lirycznym w pierwszej kolejności pełnokrwistego (!) przedstawiciela rzędu drapieżnych (carnivora), nie zaś udomowionego gatunku canis familiaris. A przecież pies jest drapieżnikiem, choć zazwyczaj nie wnika się w systematyczne zawiłości, tym samym niejako odrywając psa od jego wilczych korzeni.

Podmiotem lirycznym wiersza jest pies - $\mathrm{i}$ to pies traktowany w kategoriach figury uniwersalnej, nieprzystającej do konkretnego czasu historycznego i obszaru kulturowego. Pies Gałczyńskiego śni, a treść snu, choć ryzykownym byłoby posługiwanie się terminologią Freudowską w odniesieniu do zwierzęcia, odpowiada podświadomym marzeniom o uczcie wszechczasów. Poezja Gałczyńskiego, rozpięta pomiędzy liryczną nostalgią i satyrą, w Śnie psa nabiera humorystycznego zabarwienia. Wizja artystyczna twórcy konkretyzuje się w komicznych w oczach człowieka, koniecznych zaś w oczach psa, poniekąd atawistycznych, pragnieniach.

Czy Sen psa dedykowany jest, jak kilka innych wierszy autora Teatrzyku Zielona Gęś, dzieciom? Nie byłoby to niczym nietypowym, żeby wspomnieć o Złudzeniu popularności lub Wymarzonym kliencie. W artykule poświęconym estetyce „dziecięcych” wierszy Gałczyńskiego Teresa Wilkoń wskazała dziewięć wyznaczników, dzięki którym możliwe jest uznanie konkretnego utworu za wiersz dla dzieci. Poezja ta jest:

5 Wszystkie cytaty z wiersza Gałczyńskiego pochodzą z książki: K.I. Gałczyński, Poezje. Dzieła w pięciu tomach, t. 2, Warszawa 1957. 
1) zawsze najbardziej tradycyjna, 2) rymowana i najczęściej sylabotoniczna, 3) niezmiennie daleka od dekadentyzmu [...]. Są też inne cechy, które można by — dla pełniejszego obrazu — dorzucić: 4) obrazowość i wyobraźnię dziecięcą, 5) liczne efekty dźwiękowe (por. na przykład Juliana Tuwima Lokomotywę), 6) daleko idącą skłonność do komunikatywności przekazu, 7) częste stylizacje na różne gatunki i odmiany językowe, 8) nastawienie na konkretność języka i jego proste konstrukcje (na przykład zdania pojedyncze i parataktyczne), 9) nastawienie na funkcje dydaktyczne utworów ${ }^{6}$.

Omawiany utwór spełnia osiem z dziewięciu kryteriów, co pozornie od razu pozwoliłoby traktować go jako wiersz należący do kategorii poezji dziecięcej. Pojawiają się wyrazy dźwiękonaśladowcze: „Deszcz chlupie chlup, chlup, chlup”; zachodząca w umyśle psa zamiana pasących się krów na gorące parówki pobudza wyobraźnię młodego odbiorcy; przekaz jest zrozumiały, forma sprzyja samodzielnej lekturze. Jednak brak moralizatorskiego finału, spowodowany wewnętrzną spójnością i konsekwentnym niewychodzeniem poza obręb sfery hipnotycznej (pies przez cały czas pogrążony jest we śnie), nie pozwala wybrzmieć pouczającej puencie. Jedynie nagłe przebudzenie umożliwiłoby wprowadzenie cezury wiersza. Dlatego, jak sądzę, można uznać Sen psa za utwór o charakterze uniwersalnym.

W tym miejscu chciałabym przejść do omówienia motywu psa traktowanego w kategoriach pretekstu do postawienia przez podmiot liryczny istotnych pytań o charakterze moralno-egzystencjalnym. W tym sensie najbardziej odpowiedni wydaje się utwór Naprzód pies Herberta, silnie osadzony w kontekście dziejowym, nawiązujący do historii wystrzelenia w 1957 r. na orbitę okołoziemską suczki o imieniu Łajka. Celowo podkreślam, że było to imię, gdyż w powszechnej świadomości uznaje się łajkę za rasę.

Utwór Naprzód pies zbudowany jest z czterech strof o różnej liczbie wersów. $\mathrm{W}$ pierwszej podmiot liryczny utożsamiany z poetą stawia hipotezę dotyczącą pomysłów wysyłania w Kosmos kolejnych ssaków: psa, świni i osła. Ich śmierć ma przygotować drogę dla podboju Kosmosu przez człowieka, najważniejszego eksploratora przestrzeni pozaziemskiej. Zwrotka druga poświęcona jest wyłącznie Łajce; podmiot liryczny w przejmujący sposób podkreśla rozdźwięk między wiernością psa a jego śmiercią, śmiercią w wyniku przegrzania, a ponadto śmiercią całkowicie niepotrzebną. Porównanie kapsuły kosmicznej do budy wywołuje dysonans: i tak jak w trzecim i czwartym wersie drugiej zwrotki panuje jeszcze nastrój pogodny, przywołujący skojarzenia ze spokojnie śpiącym zwierzęciem, tak w wersie następnym rozgrzana „buda” staje się przyczyną śmierci:

więc naprzód pies poczciwy kundel

który nas nigdy nie opuścił

latarnie ziemskie śniąc i kości

w swej wirującej budzie uśnie

zakipi - wyschnie ciepła krew ${ }^{7}$.

6 T. Wilkoń, Geniusz - to zatrzymane dzieciństwo. Estetyka wierszy K.I. Gałczyńskiego dla dzieci, „Bibliotheca Nostra. Śląski Kwartalnik Naukowy” 2016, nr 1 (43), s. 44.

7 Wszystkie cytaty z wiersza Herberta pochodzą z książki: Z. Herbert, Wiersze zebrane, Kraków 2008. 
W utworze Naprzód pies poeta przyrównał badaczy Kosmosu do ludzi pierwotnych, którzy „czyniąc sobie ziemię poddaną”, eksplorują kolejne tereny, niejednokrotnie wzbudzające trwogę („na szklanym czole kroplę strachu”). Różnica polega na tym, że podporządkowanie przyrody było warunkiem koniecznym, aby ludzie mogli przetrwać, natomiast podbój Kosmosu człowieka nie ubogaca. Posłużenie się metaforą astronauty pozwoliło ukazać stan ducha współczesnych ludzi, zagubionych we własnych umysłach, nierozumiejących i niesłyszących niczego, co się dookoła nich dzieje. Współcześni ślepcy chcą podróżować na Księżyc i badać gwiazdy, a nie potrafią zgłębić tajemnicy własnej duchowości. Dlatego Herbert wymienia „,białe laski”, atrybuty niewidomych, i konfrontuje je z bytami nienamacalnymi i niepoliczalnymi: ze zmysłami i pamięcią, najlepiej wyrażającymi duchowość i człowieczeństwo. $Z$ tej właśnie przyczyny poeta wspomina o ,zapachu jabłka”, „orzeszku dźwięku”, ,ćwierci koloru” i wreszcie o „,imieniu człowieka". Dopiero świadomość posiadania wspomnianych elementów umożliwia osiągnięcie duchowego spokoju (poeta pisze o „odnalezieniu drogi”), a w dalszej kolejności stanowi gwarancję pozbawionej wstrząsów egzystencji. W ostatnich dwóch wersach czytamy:

kiedy prowadzi ślepy pies

na ziemię szczeka jak na księżyc.

Niespodziewanie pies z poczciwej Łajki przeistacza się w ślepego przewodnika, podstępnego Charona, przewożącego otępiałych współczesnych neandertalczyków ze świata duchowej wzniosłości do świata ułudy. Do księżycowego świata, w którym Ziemia staje się tak odległa i nierozpoznawalna, że z tęsknotą wyją do niej psy. Naturalny porządek zostaje zakłócony: przebywające na Ziemi psy nie wyją już do Księżyca, lecz odwrotnie. Zachwianie logiką zdarzeń, obecne także w innych utworach poety, pozwala powtórzyć za Małgorzatą Peroń, że:

Herbert jest nie tylko twórcą poezji „,kształtów oczywistych”, ale także form „,nieoczywistych”. Występują one w zaskakujących metaforach, porównaniach. Utworzony dzięki nim obraz staje się bardziej plastyczny, przemawia do wyobraźni. Z jednej strony, poprzez odwołanie do przedmiotów i kształtów znanych, staje się bliski, z drugiej zaś, poprzez odwrócenie sytuacji zaskakuje swoją oryginalnościąa .

Mimo negatywnej metafory psa-zwodziciela trudno nie dostrzec w zwierzęciu ducha ludzkiego, owego oślepionego i pogrążonego w marazmie astronauty, który już po wysłaniu w Kosmos prawdziwego psa sam stał się ślepym, bezrozumnym zwierzęciem. Herbert posłużył się metaforą czasów pierwotnych: od początku świata nie zmieniło się dążenie człowieka do odkrywania nowych ścieżek ukrytych czy to w leśnej gęstwinie, czy w przestrzeni międzygalaktycznej.

Motyw niepokoju i nieukierunkowanej jednoznacznie ludzkiej aktywności występuje również w utworze Psy Baczyńskiego. Wiersz powstał w 1941 r.; obraz

${ }^{8}$ M. Peroń, ,Ślad dłoni szukający... ”: Kształty w poezji Zbigniewa Herberta, „Colloquia Litteraria" 2008 , nr 1/2/4/5, s. 124-125. 
czasów wojennego zamętu (,wrogi obraz nieba”, „czaszkami lat”) zostaje skonfrontowany z opisem psa — symbolem wspólnie przeżytych, pełnych spokoju lat, jedynego gwaranta normalności w rozdartym konfliktami świecie. To właśnie oczy psa są nośnikiem pamięci kochanych osób, emanacją marzeń o miłości, a przede wszystkim symbolizują wartość stałą, nietkniętą przez czas. W oczach psa podmiot liryczny utożsamiany z poetą nakazuje dostrzegać symbol niezmienności świata:

Kogo kochasz? w tych oczach zastygł czas

dyluwialnych, zwierzęcych epok

i żółte, fosforyczne talerze gwiazd

wprawione w oczy jak w niebo9.

Warto zwrócić uwagę na posłużenie się określeniem „twarze psów”. Nawet cząstkowa antropomorfizacja nadaje psom szczególną pozycję stróżów ludzkiej pamięci i strażników porządku chronologicznego:

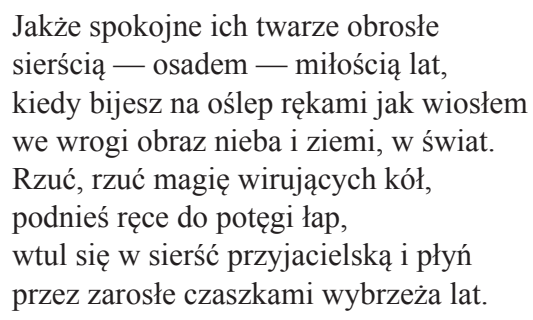

Motyw psa wielokrotnie pojawiał się w twórczości Baczyńskiego. Jeden z wierszy ( $Z$ psem) zadedykował poeta „Danowi, synowi Toma”, pisząc $P s y$ miał zaś prawdopodobnie na myśli Freda, ulubionego czworonożnego towarzysza. Według przyjaciół Baczyńskiego Fred był foksterierem, co jednak nie jest prawdą. Foksteriery (również gładkowłose) i mieszańce w ich typie nie mają żółtych, lecz bursztynowe oczy, ponadto inne umaszczenie i zdecydowanie węższą kufę.

Baczyński znany był ze swej sympatii do psów, co kilkakrotnie znalazło odzwierciedlenie w poezji. W utworze $Z$ psem pisał:

\footnotetext{
We dwu, przyjacielu, przez las,

po jasnych pętlach dróg,

poprzez polany biegnące na płask.

We dwu, przyjacielu, we dwu.

Masz twarz obrosłą, masz twarz jak ogień

jeleni natchnionych przez grom.
}

W innych utworach natomiast pojawiają się „psie” metafory i porównania, czasem o pozytywnym wydźwięku (w Wierszu o późnej jesieni psy „rozszarpią smutek" samotnej dziewczynki mieszkającej „w domu z martwej cegły i smutku"), czasem jednak o negatywnym. W utworze Lasem pies symbolizuje zezwie-

9 Wszystkie cytaty z utworów Baczyńskiego pochodzą z książki: K.K. Baczyński, Utwory zebrane, t. 1-2, oprac. A. Kmita-Piorunowa, K. Wyka, Kraków 1970. 
rzęcenie tropiących swe ofiary wrogów („Gdzie kończy się nagle fioletowym ostem — / myśliwy z psem, który też był kiedyś człowiekiem”); w Deszczach uległość i poddanie (,A tak kochając, walcząc, prosząc / stanę u źródeł studni ciemnych, / w groźnym milczeniu ręce wznosząc, / jak pies pod pustym biczem głosu”). W Darach deszczu wiosennego z kolei podmiot liryczny przedstawia obraz nagłego zatrzymania w czasie, znieruchomiałej rzeczywistości, w której pies „wywołuje zaświat ukryty w jaźni” i „patrzy w zaprzestrzeń otwartą”. Motyw psa występuje więc u Baczyńskiego wystarczająco często, aby móc dostrzec różnorodność kontekstowo-metaforyczną.

W tym miejscu chciałabym przejść do omówienia utworu Głaszcząc psa Marii Pawlikowskiej-Jasnorzewskiej. Pod względem tematycznym wiersz nie należy do wyjątkowych w dorobku poetki - wielbiącej, a przy tym uznającej wielkość Natury, dla której obecność zwierząt stanowiła znakomity pretekst do stawiania pytań o istotę miłości. Całą twórczość autorki Pocałunków, mimo ewolucji zainteresowań, można opatrzyć znakiem miłości, pełnej fascynacji, chociaż nie zawsze odwzajemnionej, miłości do kolejnych mężów i kochanków, a przy tym miłości objawiającej się w pełnych uniesienia metaforycznych sformułowaniach odnoszących się do świata roślin i zwierząt. Pawlikowska-Jasnorzewska lubiła zwierzęta, hodowała wiewiórki, a w dzieciństwie trzymały wraz z siostrą w pokoju żaby, żółwie, ptaki i psy — o czym piała Magdalena Samozwaniec („Na łóżku spały snem aniołków dwa biało-czarne bullterriery" [pisownia oryginalna - JJ] $)^{10}$.

Istotny jest kontekst biograficzny. W momencie powstania utworu Głaszczac psa (1930) Pawlikowska-Jasnorzewska była już po rozstaniu z portugalskim lotnikiem Sarmentem de Beires i jeszcze przed ślubem ze Stefanem Jasnorzewskim. Dlatego już pierwsza strofa pozwala dostrzec w metaforze psa wytęsknionego i wciąż nieobecnego kochanka. Jednakże pies ten jest także bytem rzeczywistym; on faktycznie towarzyszy poetce podczas wieczornej kontemplacji gwiazd. Zabieg poetycki polega na wprowadzeniu dychotomii między psem-symbolem (strofa pierwsza) i psem-bytem rzeczywistym (strofa trzecia), a przy tym na całkowitym, paradoksalnym i trwałym ich zespoleniu. Pies ze strofy pierwszej także towarzyszy swej właścicielce, nieświadomie inspirując ją do tworzenia lirycznych obrazów miłości, jednak to już nie on, lecz wyczekiwany kochanek zamyka oczy ogarnięte miłosnym szałem.

Miłości potrzeba pieskom, miłości jak człowiekowi...

żywności czystej jak owoc, słodkiej jak głos słowika.

Pies, pod dotknięciem rąk moich, oczy w marzeniu zamyka.

Zmrok idzie, w niebie malwowym zielony wybłysnął nowik ${ }^{11}$.

10 M. Samozwaniec, Maria i Magdalena, Kraków 1956, s. 188.

11 Wszystkie cytaty z utworu Pawlikowskiej-Jasnorzewskiej pochodzą z książki: M. Pawlikowska-Jasnorzewska, Wiersze, Warszawa 1967. 
W strofie drugiej podmiot liryczny utożsamiany z poetką stawia tezę o niezdolności większości zwierząt do przeżywania prawdziwej miłości, wskutek czego w finale wiersza wybrzmiewa pogląd na temat wyższości psa nad innymi zwierzętami. Jedynie pies zostaje uznany za tego, który wraz z człowiekiem narodził się w przestrzeni kosmicznej, a następnie przybył na Ziemię. O wyjątkowej pozycji psa w światopoglądzie poetki świadczy też stwierdzenie przytoczone już w pierwszym wersie utworu: „Miłości potrzeba pieskom, miłości jak człowiekowi”. Pozostałe zwierzęta, mimo iż stale obecne w twórczości autorki Pocałunków, w wierszu Głaszczac psa znajdują się na znacznie niższym szczeblu drabiny stworzeń zdolnych do miłości. Z jednej strony symbolizują świat łagodny, lecz skrajnie ziemski, płaski, prozaiczny i niewrażliwy na potęgę uczuć (krowy, pszczoły, pająki), z drugiej - nieokiełznany świat namiętności. Tygrysy, lwy i prehistoryczne, wymarłe ssaki stają się emanacją żądzy, którą podmiot liryczny uznaje za przeciwieństwo miłości, podkreślając dzikość rozbudzonego i niepohamowanego erotyzmu:

Miłości nie znają krowy, pszczoły, pająki, kwiaty.

Obca jest lwom i tygrysom. Nie znana jest pustce żądzy.

Czy wiedział o niej mastodont lub machairodus zębaty?

Wśród twardych ziemskich prawideł jak obca błądzi.

W strofie ostatniej po raz kolejny w polskiej poezji wykorzystana zostaje, wyrażająca galaktyczny rozdźwięk, opozycja Ziemia-Kosmos. Tytułowy pies wraz $\mathrm{z}$ autorką zostają uznani za reprezentantów porządku wzniosłego i kosmicznego:

Dziś pod globusem księżyca, siedząc z psem, głowa przy głowie,

kończę ten wiersz porzucony. Jest teraz pełnia.

I wszystko: wyraz psich oczu, mój strach, mój spleen mnie zapewnia,

że stamtąd, z księżyca — dawno — przybyliśmy: pies i człowiek...

Niech strofa ta posłuży za puentę wiersza nie tylko Pawlikowskiej-Jasnorzewskiej, lecz także Baczyńskiego i Herberta — dostrzegli oni bowiem niepojęty związek między przestrzenią kosmiczną a motywami kynologicznymi, traktując przy tym psa w kategorii pretekstu do postawienia pytań o istotę człowieczeństwa. Szymborska i Gałczyński podjęli natomiast próbę opisania zawiłości świata z psiej perspektywy. I w pełni im się to udało.

\section{„First of all, there is, and always will be, our good old mongrel..." Dog motifs in chosen Polish poems from the $20^{\text {th }}$ century}

\section{Summary}

The aim of this paper is to discuss the motif of the dog occurring in the twentieth century Polish poetry. This will entail two research outlooks: 1 . the dog as the author of a lyrical monologue, perceiving the world from an animal's point of view (Monologue of a dog ensnared in history by Szym- 
borska and $A$ dog's dream by Gałczyński); 2. the dog as the source of interest for the subject of a poem (First of all, the dog by Herbert, Dogs by Baczyński, and Stroking a dog by Pawlikowska-Jasnorzewska). The paper serves the role of an introductory article, touching upon the most important issues, foundations and literary devices used in depicting the dog motif in the above-mentioned poems. 